\title{
The Spirit of Lukiškès: a Prison as Microcosm of Modern Vilna
}

\author{
BY \\ FELIX ACKERMANN*
}

This article analyses the Lukiškés Prison as a microcosm of the $20^{\text {th }}$ century history of Vilna and the Vilna region. It tries to bring together different historical narratives on Eukiszki, Lukiškès and Лукішкi i.e. the Polish, Lithuanian and Belarusian narratives respectively. The idea is to develop a more interconnected story, one in which Lithuanian, Polish, Jewish, Russian, Soviet and also German histories, rather than being taken exclusively from one another, are seen as a part of a greater whole. The goal of this paper is to pull together these loose ends by demonstrating one succinct point: that Lukiškés Prison is a shared space, which incorporates modern strategies of exclusion, punishment, discipline and destruction.

Built as a prison in the borderlands of the Russian Empire, Lukiškès was a social microcosm that was shared by quiet different social groups that opposed imperial rule. Instead of becoming heterotopian spaces of exclusion, Lukiškès throughout the late $19^{\text {th }}$ and the first two decades of the $20^{\text {th }}$ century became a hotbed of political struggle in the Northeast of the Russian Empire. Excluding political enemies from the strictly limited imperial public sphere in the city of Vilna, the imprisonment brought them into the inner universe of ideas, programs and action. Lukiškès, despite the energy spend on tsarist style re-education programs, remained a critical space where detainees were not just well informed about the situation outside but ready for future political action. In terms of military action the power over the prison was a crucial moment during any forced takeover of Vilna during the course of the $20^{\text {th }}$ century.

The high concentration of political prisoners of any authority that had recently lost power made it a valuable reservoir from which future cadres could be drawn

\footnotetext{
* Dr. Felix Ackermann holds an MSc in Russian and post-Soviet studies from the London School of Economics and Political Science and a PhD in cultural studies from the European University Viadrina Frankfurt (Oder). Since autumn 2011 he is a visiting DAAD Associate Professor for Applied Humanities at European Humanities University, where he teaches at the German Studies Centre and the Laboratory of Critical Urbanism. A draft version of this text was presented and discussed during Colloquium Vilnense on 26 May 2015 at European Humanities University in the frame of a workshop on Belarusian Studies. The author is particularly grateful for comments by Lynn Liubamersky, Mark Berman, Volha Sasunkievič and Siarhej Liubimaŭ. He is also grateful for the feedback given by participants on a very earlier version of this text organised by Omer Bartov and Eric Weitz with support of the Guggenheim Foundation.
} 
and, therefore, a powerful factor in on-going local fights. Still, after the end of the Russian Empire, prisons as a whole remained spaces of social control and discontent. With shifting state agendas after World War I (WWI), Lukiškés increasingly became a space of the growing politics of ethnic segregation and homogenisation. Leading up to and following World War II (WWII) Lukiškès had the necessary infrastructure in place to support a repressive police apparatus, a launching point for the deportation of unwanted elements, state-sponsored mass murder and genocide. With the Soviet takeover in mid to late 1944 Lukiškès again was used by Soviet agencies to separate and punish members of the Polish underground movement as well as Lithuanians, who were suspected of being anti-Soviet. Again Lukiškés became the starting point for deportation to the Far East of Eurasia.

Built in 1904 Lukiškès Prison is of particular interest because it was formerly the most modern prison complex in the Russian Empire. The prison was the only one that officially incorporated Russian-Orthodox, Roman-Catholic and Jewish places of worship into the heart of its infrastructure. To this end, this article will combine a cultural analysis of space, religion and surveillance and the various accounts of Lukiškès as a central hub for the exclusion of political, religious and national actors under changing political regimes throughout the $20^{\text {th }}$ century. More specifically, it will discuss the role of religion and its spatial representation in Lukiškès Prison.

This article is part of a larger body of research on applied humanities in order to elaborate the relationship between theory, practice and academic self-reflection in the post-Soviet production of knowledge. For this research, it is particularly important to be visible as an acting scholar, who shapes the subject of their research by asking questions in an active manner from a perspective shaped by a contemporary setting. The text starts with a report from the prison written in the early $21^{\text {st }}$ century, as part of a seminar at a Belarusian university in exile in Lithuania.

The article uses the first historically known Latin form of the city name of Vilna, because all other names since the late $19^{\text {th }}$ century represent national claims on the former capital of the Grand Duchy of Lithuania: Wilno as a Polish city, Vilnius as a Lithuanian city, Vilne as the Yiddish Jerusalem of the North and lastly Viĺnia as a Belarusian city. The focus on the Lukiškès Prison links together the various political movements rooting in the late $19^{\text {th }}$ century and their relationship vis-á-vis each other without favouring one over another. At the same time the Lithuanian geographical name of Lukiškés is used for the prison, as far as the prisons name refers to its geographical location. The Polish version of the prison's name, Eukiszki, is used to underline the Polish context by which the inmates and city dwellers perceived the prison during in the inter war period and its aftermath. 


\section{Excursion to the Panoption: Exploring the Present of the Past}

To get to the human souls you have to climb over hundreds of fences and enter through even more doors. A place where each of your moves have been observed, were somebody else decides for you what will be done next. And the consciousness of the infinite nature of your imprisoned existence, in the midst of Vilnius, where behind many layers of barbed wire, happy and unhappy people try to live as if they were in freedom; they don't sense the on-going surveillance being carried out all over the compound - as there is no need to hide it in a place like a prison. ${ }^{1}$

With these words Natallia Nenakaromava, a first year student from Minsk opens her essay on the Lukiškes prison. After visiting the historical compound in the centre of the Lithuanian capital of Vilnius, Nenakaromava is interested in the way surveillance is carried out in the prison, one which was built more than a hundred years ago in 1904 under tsarist rule, and which went on to become a hotbed of political and cultural change in the region. Her unusual excursion to Lukiškès Prison was part of a seminar on 'The Spatial Dimension of Knowledge Production'.

After having read texts like Michel Foucault's classic writings on surveillance in modern societies, the excursion situated students in a new learning environment and made them think beyond Foucault's abstract argument (Foucault 1975, 195219). The currently functioning prison today is officially called Lukiškiu Tardymo Izoliatorius-Kalëjmas. Another first year Belarusian student wrote in an essay after their visit that, "Although the general shape of the main buildings of Lukiškes Prison is a $\mathrm{Y}$, and from the circular part of the tower straight corridors provide space for the prisoners, its overall shape does not resemble that of a panopticon. The tower in the four-story building does not allow for a supervisor to simply take a seat in the very centre and view all of prison's activity. This is why each corridor has a person charged with independently carrying out surveillance. The prison was built in such a manner as to not allow prisoners to communicate with one another' ${ }^{3}$

The student's classmate describes how he entered the prison,

Our identities are checked upon arrival. We have to cross two iron doors and after another identity check, a large gate was electronical-

\footnotetext{
1 Natallia Nenakaromava handed in the essay at European Humanities University on 10 June 2012 in Russian.

2 I have been teaching since 2011 at European Humanities University (EHU) as associate professor for applied humanities. My peculiar position as a visiting German scholar at a Belarusian university in exile in Lithuania has permitted me to experiment with various teaching methods. My research on applied humanities is supported by German Academic Exchange Service (DAAD).

3 This is a fragment of Nastassia Chazianina's essay on Lukiškès handed in at EHU on 10 June 2012 in Russian.
} 
ly opened. Only after this checkpoint did we enter the main building, a former Christian-Orthodox church, which is now a space for cultural events within the prison. If you wish to enter the complex any further, you have to pass through a giant iron gate, which is opened by a nearby guard. This is the main barrier between the outside and the part of Lukiškes, where all of the inmates are imprisoned. The emptiness is discernible after we cross through the checkpoint. The silence is pervasive and striking, and the bars' which drape over all of the windows are frightening. ${ }^{4}$

Another classmate noted about the interior that,

the cells are lined up strictly alongside the extra-long corridors. A heavy iron door encloses each cell. A small blind on each door covers a fish-eye peephole. The supervisor is obliged to pass the corridor regularly and examine each cell after a strictly fixed period of time through the peephole. ${ }^{5}$

One student wondered if

there any uniform prison clothing, or was every prisoner wearing different things? The conditions in the cells are fairly good... I even saw computers and TV-sets in them. On the other hand there are up to three inmates imprisoned in a small room at the same time. ${ }^{6}$

Another student observed:

The compound has a building that is exclusively for women. There are five fitness rooms. There is an old Christian Orthodox Church that has been refurbished and re-purposed for cultural events. And there is a special area, where working inmates live. In addition to the old Orthodox church on the prison grounds, there was also a RomanCatholic church and a synagogue erected. None of these three sites are used today on purpose. ${ }^{7}$

In the discussion that followed the visit to Lukiškès it would turn out that my students were disturbed by the trichotomy of the yellow brick walls, which recall its late $19^{\text {th }}$ century origins, the $21^{\text {st }}$ century electronic security system and the impressive iron doors, which themselves represent the $20^{\text {th }}$ century. At the same time they were surprised to find that the life of a prisoner today differs little from university life in post-Soviet dormitories. Elina Fursievič recalled an anecdote,

4 This quote is part of Irmina Lastoŭskaja's essay which was handed in on 6 June 2012 via e-mail as a part of the teaching assignments. It was originally written in Russian.

5 Nastassia Chazianina wrote this essay on the 10 June 2012 in Russian.

6 This quote is a part of Anton Slažanikin's essay written on 13 June 2012 in Russian.

7 Voliha Bartlava wrote this essay on 12 June 2012 - the original is in Russian. 
it was only after our trip to Lukiškess that I asked my friend if they could live in a prison like this. In response they said, 'Is there any difference between how life is in there and our own lives?'8

Clearly the confrontation of Foucault's theoretical analysis of a society of discipline within the actually existing post-Soviet compound of Lukiškès raised questions which the students would have the opportunity to follow-up on during their studies and perhaps beyond.

The lack of any written history on the prison as background for the students was the starting point for this text. ${ }^{9}$ Coming from Aliaksandr Lukašenka's Belarus and finishing high school under an authoritarian regime, one of the key sites for the maintenance of power by previous dictatorships in a neighbouring country had no meaning for a majority of my students, despite the fact that among Lukiškés' political prisoners there have also been quite a number of Belarusian activists. Despite its significance for the Lithuanian, Polish and Jewish national narratives of suffering and as evidence of Vilna's successive occupation by Soviet and German forces during World War II, Lukiškès is today more a vague transnational lieu de memoiré, than a subject of research on its own. Thus, after this excursion, a decision was made to set up a compact research project that would bring together these disparate historiographies. Since only brief periods of Lukiškès'story are covered by recent historiographical work, this included the exploration of the prison's history under tsarist, German, Polish and Soviet rule. ${ }^{10}$

\section{The Triangle of Punishment and the Making of Modern Vilna}

The history of Lukiškes Prison can be traced as a site that is central to the making of modern Vilna. When the Lithuanian-Belarusian-Polish borderlands were incorporated into the Russian Empire in 1795, the first wave of urbanisation began after a new railway was established that connected Warsaw with St. Petersburg in the early 1860 s. Vilna became part of a late, but accelerating process of industrial-

\footnotetext{
Written in an essay by Elina Fursievič handed in on 10 June 2012 in Russian at EHU.

9 Today the most detailed overview is available on several Wikipedia versions: in English: http:// en.wikipedia.org/wiki/Luki\%C5\%A1k\%C4\%97s_Prison and in Polish: http://pl.wikipedia.org/wiki/ Wi\%C4\%99zienie_na_\%C5\%81ukiszkach.

10 Some research has been carried out by German, Lithuanian and Polish scholars highlighting the role of the prison during Nazi-German occupation, the Shoah and Soviet repressions in 1940/41 and 1944 1953: Wardzyńska, Maria, 1993. 'Sytuacja ludności polskiej w Generalnym Komisariacie Litwy czerwiec 1941 - lipiec 1944', Warszawa; Dieckmann, Christoph, 2011, 'Deutsche Besatzungspolitik in Litauen 1941-1944', Göttingen, Vol. I + II; Pasierbska Halina, 2003. 'Wileńskie Łukiszki na tle wydarzeń lat wojny 1939-1944', Gdańsk; Bubnys, Arūnas, 1998. 'Vokiečių okupuota Lietuva (19411944)', Vilnius; Arad, Yitzhak, 'The Murder of the Jews in German-Occupied Lithuania (19411944)', in: The Vanished World of Lithuanian Jews, ed. Alvydas Nikžentaitis, Stefan Schreiner, and Darius Staliūnas, Amsterdam 2004, 175-198. There are some popular accounts of Lukiškés, which are treated rather in regard to their commemorating character as a document itself: Krajewski, Józef, 2011. 'Wojenne dzieje Wilna 1939-1945. Losy Polaków. Sensacje. Zagadki', Warszawa.
} 
isation within these ethnically complex borderlands. The new railway stripped the north-western border regions of the Russian Empire of their rather peripheral status within its tsarist socioeconomic-geographical context. New factories produced consumer goods out of flax, wood and agricultural goods from the region and could now sell them all over the Russian Empire. The share of industrial workers steadily rose over time among both the Jewish and Christian communities (Goshkevich 1905, 24-27). This new flow of capital from within the Empire created conditions that would lead to the construction of large brick houses.

Vilnas' potential was reassessed by the tsarist administration. The administration would go on to create a plan for a new town outside the old walls of the city. In the $1880 \mathrm{~s}$, the major intersection of what today is called Naujamestis became Georgievskii Prospect (it was later named Mickiewicz Street in Polish and is contemporarily called Gedimino Avenue in Lithuanian) (Jogèla 2008, 108-116). The eclecticism of the first houses combined neo-baroque elements with other historical styles, a consequence of the influence of St. Petersburg's Nevskii Prospect (Lukšionytė 1980, 89). At that time several large open voids between buildings could be found on the newly built avenue, demonstrating that Vilna was much smaller than St. Petersburg and that the flow of capital from the centre of the Russian Empire was still rather limited. By 1890, the development of Georgievskii Prospect was limited and the suburb maintained a more rural atmosphere, including a variety of one and two-storey wooden houses (Jogèla 2008, 118-120).

The western end of the new avenue was located in the suburb of Lukiškes, a historical quarter for the Tatar community and village dwellers (Jogèla 2008, 133-166). The vast empty square at the centre of this area was still considered to be outside of the city's limits up through the late $19^{\text {th }}$ century and it was primarily used as a market (Jogèla 2008, 200). Jews and other inhabitants from Vilna bought here goods from local peasants, most of them speaking a Slavonic vernacular somewhere between Belarusian and Polish. Also the historical Kaziuki market was held annually on Lukiškès Square in early spring for all the residents of Vilna and the surrounding area (Lietuvių enciklopedija 1958, 509).

Due to its public character, and its location outside the city walls, Eukiszki became the site where the executions of the 1863/64s insurrectionists were carried out by the tsarist authorities. The public hanging of their leader Kanstancin Kalinoŭski and eight other participants of the popular uprising, as well as several executions by firing squad, were carried out in public in the rear part of Lukiškès Square close to St. Jacobs Church (Girninkiene 1991, 55). Although the Russian governor Mikhail Murav'iov intended for their prosecution and punishment to be public, their death sentences were administered outside of Vilnius' city centre.

At the same time, the prisons that were then being used for detaining inmates could not find space for those insurrectionists who were not sentenced to death. 
Both major insurrections, in $1830 / 31$ and $1863 / 64$, were not only savagely put down, but also a led to surge in the population of prisoners from various social backgrounds (Jogèla 2008, 163). Thus, following prolonged discussions on enlarging the tsarist prison infrastructure, these events forced the authorities to enlarge the region's prisons' physical capacities (Kriukelyte 2012). The dilemma for the tsarist authorities, however, was not solely an issue of the number of cells to be made available, but rather it also one which took into consideration the quality and the purpose of a person's detainment; A consideration that evolved in the years following the uprising (Johnston 2000, 126-127).

The Russian legal system was itself reformed in 1874 with redefined sentences for the convicted, establishing both a brief six month sentence and a longer six year one (Vinogradov 1905, 320). A new representative building for the higher court of the so-called North-western District was built on Georgievskii Prospect on Eukiszki square during the 1880s, exactly opposite the area used for public hangings (Jogèla 2008, 153-156, 231-236). After decades of improvisation with detainment at a small prison in the Lukiškess area, the tsarist authorities started to discuss the implementation of a modernisation project for a new detainment policy in Vilna. ${ }^{11}$ The plan called for the erection of a new complex that would contain a modern prison infrastructure that was modelled on St. Petersburg's Kresty Prison, construction of which had been completed in the late 1880s (Donghi 1925, 75-80). The decision to finally build a modern prison complex was taken only at the very end of the $19^{\text {th }}$ century, when Eukiszki was still perceived to be a remote area (Jogèla 2008, 134-135). The compound, which contained heating and air ventilation systems, integrated workshops and a hospital was finally completed in 1904 after 15 years of construction. Alongside the area designated for public hangings on the square and the higher court building, it created what can be deemed Lukiškès' 'triangle of punishment'.

Ironically, its erection happened at the same time as a phase of rapid urban growth in Vilna at the turn of the $19^{\text {th }}$ and $20^{\text {th }}$ centuries. It was at this time that Georgievskii Prospect period was extended beyond Lukiski Square. Among the new buildings were simple houses of the same yellow brick as the prison and some Jugendstil houses like those found in St. Petersburg's Petrogradskaia storona (Reklaite et. al. 2013, 20). Together, they would situate the prison into an identifiably more central urban setting. While it was designed to be built up on the outside of the old core of Vilna, the most modern tsarist-era prison facility to be found in the West of the Russian Empire was itself overrun by the surrounding rapid urban growth of the

\footnotetext{
11 I use this version of the toponym as something in common between the different existing options: Lukiškès in Lithuanian, Lukishki in Russian and Lukiszki in Polish. Although there is a strict link between its erection and the Tsarist regime in the region, it is not to claim a privileged heritage of this period.
} 


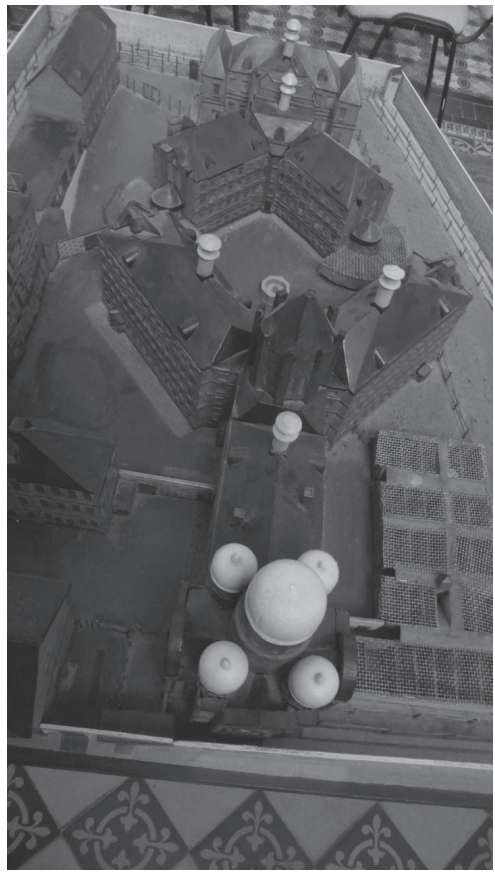

FIGURE 1: Model of Lukiškès prison

earlier $20^{\text {th }}$ century. Paradoxically, it was in fact an integral part of this growth and was even perceived as a symbol of this process of urbanisation. When Vinogradov published the second edition of his Vilna guidebook in 1905, Lukiškès Prison was already mentioned as a beautiful site for recreational walks as, 'the last word on technique and different dimensions of perfectionism' (Vinogradov 1905).

The architectural modernisation of Vilna had just begun. While Georgievskii Prospect was extended even further out, there were very few new houses alongside the Neris River (Jogèla 2008, 126). Prisoners could see from some Lukiškès Prison's windows from Upper Castle Hill. One of the first Lithuanian political prisoners, Visuomis D. Šidlauskis, shared his impressions in his diary this way, 'the two windows of my room are directed towards the Antakalnis hills. The view is very beautiful: unequal, overgrown corner of the hill: To the right the Gediminas hill. There various trees are growing. Beyond them a small building is visible' (LMAVB RS f. 12, b. 2228, p. 7).

\section{Part of a Global Network of New Ideas and the Practice of Re-Socialisation}

The modern architecture of Lukiškès is a hybrid of the spread of reformist ideas throughout Europe in the field of imprisonment and its tsarist interpretation, which 
took into consideration some local peculiarities. A special prison commission discussed its establishment in Vilna, which was in charge of negotiating with the Russian Minister of Justice the conditions of detainment, that would, in turn, shape some architectural details of the new prison (Jogèla 2008, 136-137). At the core of this process was a shift in the understanding of the function of prisons. A move away from simply punishing and also from public torture, it focused more on the re-socialisation process of detainees. By the implementation of a spatial model, commonly known as a panopticon, developed in the United States and transmitted to Russia after it made its way to the United Kingdom and Germany, Vilna became part of the global spread of this new model of detainment (Carlson 1999, 28-33). But this was not just a mere migration of ideas from the West to the East. Rather, it started with the adaptation of an idea in $18^{\text {th }}$ century England that has its origins in traditional Belarusian lands.

The initial point of reference for Foucault's theoretical approach towards panoptical prisons was Jeremy Bentham's project for a new British detention centre (Johnston 2000, 127). This famous panopticon, proposed by the reform advocate Jeremy Bentham, was never built. Yet far more crucial for Foucault was the idea behind the project, rather than the material implementation of it. An important forgotten detail about the idea of the panopticon was that Jeremy Bentham borrowed it from his younger brother Samuel. Samuel was a wellacknowledged naval engineer and businessman that supported Prince Potiomkin's fleet. The Russian Anglophilia of the time brought Bentham junior to the Western borderlands of the Empire, where he became the estate manager of Kryčaŭ, which today is located in Eastern Belarus. Samuel Bentham developed the first version of the panopticon in Kryčaŭ in response to two questions: How to deal with the lack of skilled workers in the Russian Empire? And how to control serfs, who were not working on a contractual basis and therefore were less motivated? The panoptical structure with a supervisor at the centre was the economically most efficient solution for constant surveillance that he could devise. It was Jeremy Bentham who took this idea after a few visits to Kryčaŭ from the Russian Empire to the West and combined the economical cost cutting aspect of this model with his own reform agenda (Stanziani, 2009).

A major shift away from the monarchical practice of public torturing to a more specialised system of professional punishment also found footing in the Russian Empire (Foucault 1975, 195-219). While public torturing appeared in Russia more than half a century later than in France, the case Foucault begins his work with, it still had a similar outcome. The multiple Russian prison reforms that were proclaimed in the $19^{\text {th }}$ century introduced some of the major features of modern technologies of punishment, a development that completely changed the way of dealing with prisoners in order to bring them under a certain level of the state's 
control (Frank 1999). One need not agree with the idea of constant self-policing in regard to tsarist prisons, but Foucault formulates a strong argument about the spatial link between architecture, knowledge and power. Using this argument in the Russian-Lithuanian context leads to a surprising revelation that the very heart of surveillance was shaped by religious spaces (Gernet 1941).

In Vilna, the Orthodox Saint Nicholas Church, integrated by the architect Konstantin Kelchevskii into a prison complex, played a major role in structuring the inner space of the prison's yard (Jogèla 2008, 137). For one, it symbolically represented the power of the state of the Russian Empire with its official state religion. It was also the most visible structure within the complex (i.e. visible from the inside for the inmates and from outside the prison as well). Similarly, as in London's well-known Pentonville prison, in Vilna a church was situated right behind the entrance as an architecturally dominant feature. In the Russian Empire this religious symbol, as a representation of the Empire's religion, had to be a branch of the Russian-Orthodox church. The impressive neo-byzantine architecture of St. Nicholas was the spatial and visual starting point when approaching and entering Lukiškès Prison. It defined the complex's main horizontal axis and set up a dominant vertical vanishing point.

This religiously defined space was not just thought to represent imperial power, as it was being asserted in what were essentially foreign lands, a region where the Russian Orthodox Church in urban settlements made up a tiny minority. The large church buildings were also symbolic representations of the inner logic of modernisation with its core idea of progress. Following a global trend of the early $19^{\text {th }}$ century reform movement, they were thought to be spaces of inner recollection that could lead to prisoners' self-betterment (Adams 1996). To that end, reformists in America and all over Europe argued for the modernisation of the physical and social prison infrastructure itself. After the adoption of the radial U.S. Pennsylvania system as a model for British prisons, the circular design with a chapel at its centre made its way throughout continental Europe (Johnston 2000, 87-112). In the case of the Russian Empire, reintegration into society was only possible via an encounter with the right religion, and in Imperial Russia this was, by definition, taken to be the Christian-Orthodox faith. Without a strong modern belief in the possibility to transform people for the better while under state custody, it would have been irrational to invest large sums of money into any new conceptualisations of imprisonment, be they physical or social, at all. It is remarkable that these ideas, after some experimentation in Staraja Russa in 1884 and the building of the central Kresty prison built in St. Petersburg in 1892, spread to almost all corners of the Empire, including those in the north-western borderlands. 


\section{At the Centre of Vilna's Political Scene}

Only a few decades after the last insurrection, the Lukiškès Prison became a microcosm of Vilna's new political movements; Prominent members of all colours of the political spectrum, whom were perceived as challenging tsarist statehood, were imprisoned at Lukiškés (Lietuvių enciklopedija 1958). An explosion of political activism in the 19th century paralleled the economic modernisation and urbanisation processes of the time. While oppressive tsarist rule in the growing urban space of Vilna was notable, it still provided some room for the expression of new political ideas. As a result the city became a hotbed of both cultural and political activism, which challenged not only the tsarist regime from the inside, but also extended to contesting traditional relations between different generations, social classes and ethnic groups (Weeks 2013).

Lukiškès became the 'place to be' for convicted political enemies of tsarist rule; the more radical one was, the more likely to be imprisoned in Lukiškès. Thus, the prison became a hotbed of activists, representing various ethnic, political and social groups under the ruling Russian bureaucracy. The growing share of workers, among the overall population, were in turn mobilised by the new ideas they encountered, like the principles of socialism and communism. Among the first generation of Lukiškès prisoners was the Lithuanian socialist activist Visuomis D. Šidlauskis (LMAVB RS f. 12, b. 2228). He was imprisoned in 1905 for a rather short period of time and described the prison as a place of exchange between very different types of people. In a diary he kept, also quoted above, he wrote down a verse from one of the walls of the women's prison:

As a matter of senseless trials

I sit in the chamber number 14

The attentive Milda and Vènèra

Did send me five God virgins:

Nadia, Viera, Suročka with brown hair,

Plus the blond Sonia and Vieročka

The days were like spring:

The window was full of elderflowers and all around we felt a wonderful smell.

One or the others picked some flower

And full with kisses handed it over to me

Deemed to repentance

I returned to the paradise. ${ }^{12}$

12 Ebd. Authors of the text were likely O. Belkevičaite und I. Polkovskiene - the text was written in Russian rhymes, p. 5. 
The humorous tone is not congruent with other parts of Šidlauskis' diary, where he describes the prison as a space of exclusion, especially for his political comrades from all over the region. Lukiškés appears as a meeting point for those who opposed the tsarist regime and were looking for new ways to organise society (LMAVB RS f. 12, b. 2228, p. 7 ff.). At the same time competing national projects were established and for all communities in the region, Vilna was a central focus point. For the nationalist activists from the Lithuanian quarter, it was Vilnius, whereas the alias Vilnia in Belarusian projected visions of a city that would become the future capital of a sovereign state. For the Polish and Jewish national projects, Wilno was not merely an imagined capital but a remarkable source of authenticity. At the same time, several political alternatives were formulated. Among them was the regionalist project of the Krajoŭcy, who dreamed of a non-ethnic definition of Lithuania as homeland of all people living within its borders (Smaliančuk 2004).

The competition between different political and cultural projects was a rather complicated manner. The Jewish population of Vilna, for example, divided their allegiances up between the socialist movement of the Bund, the Zionist parties and the communist underground, all of which suited different groups in the social strata of the Jewish community. Interestingly, while the communist movement was generally internationalist, the Bund was a strictly Jewish organisation. Yet despite their differences, most of the political movements strongly opposed tsarist autocracy and fought for their version of social, economic, cultural and political self-determination. In fact they were given even more impetus by the events of 1905, when the tsarist authorities tried to cope with further pressure from a broad range of actors. The tsarist answer was a certain degree of self-representation and a mix of force. As far as certain categories of political enemies remained in charge, prisons at this crucial point leading up to WWI started to become modern heterotopias of individuals who were excluded by force from the resolutely limited avenues of parliamentary representation.

Consequently, prisons in the region were constantly full of individuals from highly diverse social, ethnic, religious and political backgrounds. At Lukiškès, for example, there were a number of outstanding political figures such as the founder of the Bolshevik's political police Cheka, Felix Dzerzhinsky, who was imprisoned as a communist under tsarist rule (Lukiškių tardymo izoliatorius-kalèjimas 2014). A leading figure of Viĺnia as a centre of Belarusian cultural activity, Francišak Aliachnovič, was imprisoned in 1914 and used his stay in prison as involuntary 'time-out' to write the drama ' $\mathrm{Na}$ Antokali' about the dilemmas facing the Belarusian bourgeoisie in one of the local suburbs (Aliachnovič 1994). While in prison the manuscript was put out in a Polish language edition, and Aliachnovič 


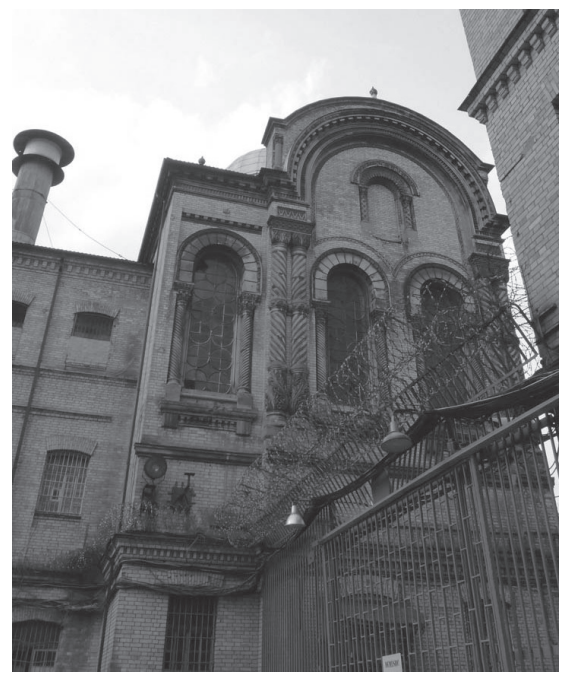

FIGURE 2: Church at Lukiškès Prison

translated it himself after being released in 1915 into Belarusian before the play was shown by a Belarusian theatre group in Vilna. In another prominent case Jonas Vileišis, an editor and leading figure of the Lithuanian national movement prior to WWI, was imprisoned by the German authorities during WWI after he was caught circulating leaflets criticising the occupation. As with katorga in tsarist times, after his detention in Lukiškés, Vileišis was sent to do forced labour in Germany (Kapočius 1970/78, 124-125).

A more in-depth analysis of who was in prison should also pay attention to those who were not imprisoned at this time. Of course, the tsarist regime was careful to not have a large number of its own representatives in these 'borderland' prisons. Rather, it detained those who opposed the Russian Empire itself. Those who supported the Empire's presence in these borderland regions would find their way in one of these prisons only after committing an 'ordinary crime'. Due to the complex nature of the nationalisation of political thought in different communities and their activity throughout the late $19^{\text {th }}$ century, more and more political prisoners began to represent the local regional branches of different nationalist movements. This does not diminish the significant number of social revolutionary and communist activists, who most often were from the region, but did not link their programme to any specific ethnic group or national movement. Over time the tsarist prison policy was more and more a reflection of the ongoing nationalisation of an internal and often symbolic struggle for power. 


\section{Secularisation? The Declining Role of Religion}

Religion was at the core of the tsarist idea of re-socialisation and in the 1880s it was an essential part of the Russian Imperial modernisation project. The Lukiškès Prison represents this core idea up to the $21^{\text {st }}$ century, though the role of religious spaces in fulfilling the mission of the prison diminished over the course of the $20^{\text {th }}$ century. The physical space of Lukiškès was not just defined by its high walls, the characteristic large yellow bricks of its administrative buildings, or an openly eclectic approach towards the architectural achievements of the past. Rather, at the core of the prison the architects made space for three places for religious worship. First, there was the Russian Orthodox Church of St. Nicholas, characterised by its highly visible expressive neo-Byzantine style, less visible to two of the jail houses, which is not indicative of the importance of the structure.

As in St. Petersburg's Kresty and other modern prisons, these large complexes were built in a panoptic manner with central rotundas that had circular wings and cells on five floors each (Stanziani 2009). In place of right-angled wings, the two buildings in Vilna united three wings. At the very centre of this propellerlike circular setting, a Catholic church was erected, and in the centre of the other one a synagogue was built. In these radial prison buildings an altar and a bimah were to be found on the third tier. Stairways and platforms inside were arranged in such a way as to allow prisoners to be able to worship on Saturdays or Sundays. They would simply need to gather at the very centre of their respective tier to do so. ${ }^{13}$ Instead of a supervisor that was able to constantly control prisoners like the one found in Foucault's prototypical panopticon, in Vilna a priest and a rabbi are believed to have been the ones speaking to prisoners from a central point. While the Orthodox church was visible from the outside and needed to be approached by prisoners on special terms, the Catholic chapel and the synagogue filled out the centre of both of the prison buildings that contained the most cells. From the outside only some elements of the roof's construction made these religious spaces recognisable to the uninformed.

Even if the formal shape of the prison says little about their content, it is remarkable to note that in Vilna, a city with a Jewish majority and a large share of Catholic inhabitants, tsarist planners came with a vision of bettering prisoners' mental health through religious education from the Orthodox Christian faith, prescribing it as the only proper faith for an area that was religiously diverse. The prison structure itself still refers to religion as a central element of identity in Russian imperial thought, but to a certain extent it still invites the reality of these historically non-Russian lands into the picture as well. This is not to claim

\footnotetext{
13 This setting is not an innovation from Russia. E.g. earlier Italian projects contained a central altar in the very centre of a radial building. Ministero di Grazia e Giustizia, 1994: Immagini dal Carcere, Genoa, 146.
} 
that the tsarist authorities met the needs of all its prisoners. We know very little about the use of these religious spaces and even less about how they were perceived by different groups of prisoners. But even though it is a physical symbolic representation of the cultural situation in this part of the Empire and beyond cultural representation of tsarist policies, it shows some attempt at having a programmatic approach at shaping the prison not just for representational needs, but to make it function in accordance with the initial intentions of the reform agenda that stood behind it.

Symbolically, there is still a well-prescribed order among these three religious structures, namely, their positioning. The Orthodox Church is disconnected from the cells themselves and is situated at the very opening of the complex. The Catholic chapel is inside the first prison building, which contains the largest number of cells, which places it in second in terms of its prominence (Johnston 2000, 126-146). This is partially due to its close relation to the Orthodox Church and also to the visibility of its neo-romantic roof construction. ${ }^{14}$ In material terms, the construction of the Orthodox church was five times more expensive than that of the Catholic church. The Orthodox church also had three bells, while the Catholic church possessed none (Jogèla 2008, 137-138). Formally, St. Nicholas was the only place a prison priest served, while visiting priests from the nearby St. Philip and Jacob Church were denied official status as prison chaplains. The synagogue remains symbolically remote, although it is clearly linked due to a strong axis connecting all three buildings. It is remarkable that this state driven order of religions and confessions in the late Russian Empire made the case for a prison space defined in Jewish terms. But even given this, it is still at the bottom rung of the representational symbolic ladder.

One could conclude that in Lukiškes the principle of the panopticon was transformed in accordance with Russian prison reform thought into a hybrid space of state surveillance and religious encounter which intended to create better prisoners as future members of society. Further research on the everyday life of prisoners and the impact of further political events such as WWI or 1905 should pay attention to how tsarist surveillance was carried out in practice in cooperation with priests of all three denominations. Beyond the empire it is meaningful to understand how new state and religious actors throughout the $20^{\text {th }}$ century transformed these religious spaces. At Lukiškès the Soviet authorities after WWII used the Orthodox Church as a dom kul'tury, cultural centre, and stripped it, as they similarly did with Catholic Church, of its prior religious function while maintaining the core features of its

\footnotetext{
${ }_{14}$ We have little knowledge about the everyday practices in the prison during the 1920s and 1930s. The first official Polish priest serving as a prison chaplain came from the St. Jacobs and Phillips Church nearby. Piotr Rynkiewicz during WWII became also a priest within the Armia Krajowa underground military organisation (Lubkowska 2014).
} 
architecture. Only the former synagogue, due to the construction of a new heating system, was more or less torn apart. Only the shape of the rooftop today hints at its previous existence.

The strong intersection between surveillance and religion at the very core of Lukiškès' architecture became a major argument for preserving large parts of its shape throughout the $20^{\text {th }}$ century. Even during the Soviet period, the Orthodox church was a spatial resource closely tied to other administrative parts within the prison and was not destroyed. For its part, the architecturally Roman Catholic defined space linked the wings of prison cells like the synagogue in the second building did. Therefore, even after the role of religion in terms of prisoner surveillance declined, the buildings still represented the initial ideas of the tsarist reformers.

\section{An Infrastructure for Radicalised Political Repression and Mass-Murder}

The emergence of the Lithuanian and Polish nation-states in the aftermath of WWI was a success for both national movements, yet they were still opposed to each other and competing for Vilna. While the Chief of State of the Second Republic of Poland, Marshall Józef Piłsudski, and his legions pushed over the next two decades by military force Poland's claims for the city in 1920, Lithuanian society with its 'temporary capital' in Kaunas promoted Vilna as a Lithuanian capital through a mass movement (Davoliūtè 2013, 27-31). At the same time the communist and socialist ideologies were still attractive and legitimate options for many inhabitants of Vilna. The Polish administration perceived local communism as a branch of Bolshevism and a major threat. As a result Lukiškés, as the largest and still most modern prison in the Northeast of the Polish Republic, remained a central place for the exclusion of political enemies.

Among the political prisoners held in Vilna were Belarusian, Jewish and Lithuanian nationalist activists, but the largest group were communists from different social and ethnic backgrounds (Kuznitz 1998). Among the Lithuanian political prisoners during the Polish period was Petras Česnulis, an activist who was brought to Łukiszki in late 1936. He was held in there during the legal process, which took place nearby at the court building at Łukiszki Square. Česnulis was sentenced to 15 years in prison and brought to the prison of a former Jesuite monastery in Hrodna, less than 200 kilometres southwest of Vilna. He describes a rising number of the Lithuanian political prisoners at the very end of the 1930s in his writing. He wrote a book while in exile in 1973 that addressed the harsh conditions for political inmates in Polish prisons during the last three years of Polish power over Vilna and the surrounding region. With an anti-Polish focus, he 
highlighted the tensions that existed along national lines among the prisoners at both Lukiškès and Hrodna (Česnulis 1983, 79-97).

The prison's function remained much the same during the Lithuanian takeover in September 1939. While the east of the Polish Republic was divided up between the Soviet Union and the Third Reich, Vilna and its surroundings came under Lithuanian rule. The new government started to replace the Polish prison administration with Lithuanian cadres. In the very first days of the Lithuanian takeover the prison was rather overcrowded, a state it would constantly endure during WWII (Lewandowska 1997, 22-23). Another regular feature of the prison was a focus on detentions of political enemies such as communist activists alongside ordinary criminals. The number of ethnic Polish inmates also rose significantly compared to pre-1939 figures.

In June 1940, Vilna became the official capital of the Lithuanian Soviet Socialist Republic. Even with the communist takeover of the city, the prison itself continued to function in the same manner as it had previously. It still had the necessary modern infrastructure for successive political regimes to detain political enemies and isolate them from the public. Now, of course, the political agenda had been diametrically changed and advocates of the Polish, Lithuanian, Jewish and Belarusian national projects were persecuted. Among the most famous prisoners was the Zionist activist Menachem Begin, who was sentenced by the Soviets to eight years of hard labour in Siberia. Begin would go on to survive the Holocaust and become the premier of Israel. In 1940 he was arrested by the NKVD and interrogated at Lukiškès Square, the NKVD headquarters, later to be imprisoned at Lukiškess. Not only was the political focus of repression altered with the Soviet takeover of Vilna, but the new regime brought with it a new dimension of violence to Lukiškès, one which went far beyond the former tsarist usage of ssylka. ${ }^{15}$ Executions, both carried out in the court building at Lukiškès Square and in the prison complex over the various stages of Soviet occupation became a regular practice.

The imprisonment of suspicious persons, some of them former political activists, but often just persons with the 'wrong profession' or owners of large houses was a regular technique employed by the Soviets and it was organised in a considerably more brutal fashion than under previous regimes. Among the new inmates of Lukiškès were now many representatives of pre-war Wilno, many of them based on their social status. Among them were professors of Stefan Batory University, members of former paramilitary organisations such as the Polish Scout organisation and many other random victims. Under Soviet role, Lukiškès

15 The deportation of political enemies to Siberia or the Polish and Lithuanian practice of isolating the state's political enemies from the public. 
once more became an important point of transit; it was the first stop in a long line of future detentions and imprisonment. Beginning in early 1941, several major waves of deportation to the East and South of the Soviet Union were carried out (Pasierbska, 28ff). Lukiškés, from a Soviet point of view, was the perfect place to collect its detainees for a few days before they were brought to deportation trains. The last wave of deportation of various representatives of pre-war Wilno started in June 1941 (Bubnys 2009, 6). One detainee recalls his stay at Lukiszki:

On the morning of 19 September 1941, I was arrested by NKVD. After a very thorough search of my flat I was taken to the Vilna prison on Łukiszki. After 'welcome ceremonies' that included a personal revision, an official photo session, fingerprinting and other similar procedures, I was taken to a prison cell. This was a small cell for one person, but I was already assigned a number for. During the first interrogation I was accused of article 58 - counterrevolution, and more precisely the organisation of a political-militant organisation. In the beginning they still tried to convince me that if I would confess everything on a voluntary basis I would be a free man the next day! But I already knew the Bolsheviks quiet well. For the next interrogations I was woken up in the middle of the night, sometimes twice. If one is to add to this the threats, the curse words and all the insults on behalf of the interrogators - among them the forced look at a naked wall for hours, you would get some picture of how exhausted I was after a while. I should add that during the day I was brought to interrogation right before lunch and supper, to make sure, that I would get no food during the day. I had not enough to eat. We got 600 grams of bread every day, a litre of soup for lunch and a litre during supper. Plus a tiny amount of sugar. That was it. The Łukiszki prison, which was run until recently by Lithuanians, when compared to other places, was a hot bed of hygiene and order anyhow. It was precisely this order that was expressed by the fact that it was impossible to talk loudly or to come close to the windows, which were covered with metal. This added to my state of mind, which became weaker and weaker every day. Anyhow the general mood among Poles in the prison was good, because we knew that this would not last forever. Before the outbreak of war between the Soviet Union and Germany, my trial was put on hold. On Sunday 22 June 1941, on the very first day, the Germans started to bomb Vilna. During the night of the $22^{\text {nd }} / 23^{\text {rd }}$, the Bolsheviks started an evacuation of the prison. During the morning before the bombardment of the city, we were brought to a freight depot. As I 
learnt only later, a bomb hit one car and some prisoners managed to escape. During the $23^{\text {rd }}$ and $24^{\text {th }}$ we were waiting in closed wagons on the train station - aware of the danger that a bomb might have hit the wagons at any second. During the night we recognised the noise of artillery, than of tank units, and in the morning that of automatic gunfire. The Germans were already in the suburbs of Vilna. At this moment the train started off. Close to Vilna our train was hit for the first time (Gross and Grudzińska-Gross 1983, 183-188).

From the very beginning of the German occupation during WWII, Lukiškès played a major role in the further social destruction of Vilna. Already by 1 July, there were 1,577 prisoners, many of whom were detained for political reasons (Bubnys 2009, 11). In the first weeks and months, the majority of new inmates were Soviet prisoners of war, Soviet officials and Jews (LCVA F R730, apl. 1, b. 218, 12, 566, 338; LCVA F R730 Opis 1 Akte 1276; LCVA F R689 ap. 4, b. 916, Masinès žudynès Lietuvoje, d. 1, p. 137). According to the German Kommissarsbefehl, the Wehrmacht and special police units were supposed to 'cleanse' the newly occupied territories of any Communist actors (Bubnys and Kuodyte 2005, 104-117). In late July in Vilna there were already almost 200 executions carried out. The terror being wreaked on a daily basis, in particular open violence against the Jewish population, started to gain momentum and become the norm (MacQueen 2003, 117). Lukiškés was a spot where, under German supervision, the units of the Security Police Saugumo Policija and other predominantly Lithuanian collaborators brought Jews, caught on the streets, in to be detained.

The ongoing radicalization of German policies toward the local population made the borderlands of Lithuania, Belarus and Poland a particularly brutal region for victims of the systematic murder of the European Jewry (Hoppe 2011, 560). The tsarist prison infrastructure itself was not decisive enough to carry out genocide (Bubnys and Kuodytė 2005, 19). But German police used central prisons like Lukiškès to gather its victims before killing them in a more peripheral setting. In Vilna it was the nearby settlement of Panary, where daily mass murder took place (Kruk 2002, 53). Local knowledge about the ongoing mass murder was widespread. Kazimierz Sakowicz, a Polish journalist that lived nearby and wrote an entry in his diary in which he noted that the first transfers from Lukiškès arrived as early as July 1941 (Sakowicz 2005).

When the two ghettos were created in late September 1941, Lukiškés became a major gathering site for the regions' Jewish population before they would be sent off to Panary to be executed. On 1 October about 1,700 Jews were brought to the extermination site outside Vilna from Lukiškess Prison (Spector and Wigoder 2001, 1401). Another 2,200 followed the next day. During October, the small Vilna 
ghetto was almost entirely liquidated. Those who did not prove their ability to work productively were brought to Lukiškes Prison alongside with their families, collected in groups of hundreds and sent on to their final destination in Panary. This all continued until the end of 1941. At the beginning of 1942, only those Jews who were formally accepted as workers and their families remained in the ghetto. This lull in the mass murder of the ghetto's Jewish inhabitants ended in March 1943. During the 'liquidation' of the remaining ghetto in September 1943 the last Jews of Vilna were sent to and killed in Panary (Yitzak 2009, 133-145).

With more than 60,000 Jews, they were by far the largest group of local victims during WWII. Roughly one third of all the inhabitants of Vilna became victims of genocide, the majority of whom had their last stop back in their native town at Lukiškess Prison. Among those non-Jews killed in Panary were Soviet prisoners of war, Soviet bureaucrats, members of the Polish underground, Russians, Lithuanians and victims with various other backgrounds. On 2 October 1941, Valerijonas Knyva, former minister of agriculture within the Lithuanian Socialist Soviet Republic, embarked on his last trip from the prison to Panary (Bubnys 2009, 13). In December 1941, six Poles were murdered at the same spot after their imprisonment in Lukiškes (Pasierbska 2003, 233).

The overall radicalisation of German policies against the local population had an impact on the further treatment of local non-Jews as well. In 1942, the German terror, partially carried out at the hands of Lithuanian units, started to be directed more intensively against the local Poles. Among the activists that were taken to Lukiškés and later murdered in Panary were members of the Zwiqzek Wolnych Polaków, a Polish underground organisation (Bubnys 2009, 17). From 1942 onwards Lukiškès also became a site of public collective punishment, when well-known representatives of the local Polish community where arrested and essentially taken as hostage to put pressure on a whole national group (Piotrowski 2008, 167). After the German authorities sentenced them to death, dozens were killed in the same pits where the Jewish population of Vilna had previously been murdered.

During the summer of 1942, Polish priests were imprisoned as a result of a secret printing workshop being discovered at a church compound near Lukiškès. Following several individual cases of repression against Catholic priests in 1942, virtually all members of the Catholic clergy were arrested and brought to the prison. This was a major blow to the Polish Catholic clergy, and indirectly to the Polish community of Vilna. However, most of the imprisoned nuns and monks were not shot in Panary. Things were worse for other Polish inmates like Ryszardas Kucharek, a young man from Niemiančyn, who was thought to be a member of an underground organisation (Pasierbska 2003, 79). ${ }^{16}$ Other prisoners were

\footnotetext{
${ }^{16}$ The spelling follows the quoted document.
} 
brought from Lukiškés to various labour camps. Among them was the Jesuit priest Stanisław Sowa. He was arrested in March 1942, brought to Lukiškés and died on 13 April 1944 from exhaustion in a small labour camp called Szałtupie, close to Vilna (Wilczur 2005, 56; Sacrum Poloniae 1965, 234).

Furthermore, the prison itself became a regular killing site for inmates from other various backgrounds. On 13 April 1942, the German soldier Anton Schmidt was shot in Lukiškès after he was sentenced to death for aiding Jews by hiding and providing them with transportation to commute between different ghettos (Hoppe 2011, 49, 609). On 24 November, in the second yard, the execution of Stepa Kiruli a 17-year-old Lithuanian, was carried out, ignoring his request for a pardon (Bubnys 2009, 44).

Other prisoners died as a result of the brutal violence carried out by the Lithuanian guards, the German SD and SS members in the very same spot. Among them was the Jewish politician, who until September 1939 was a member of the Polish parliament, Jakub Wygodzki. In July 1941 he arranged a meeting with the German officer who was in charge of Jewish issues at the local branch of the Gestapo to argue on behalf of Vilna's Jewish population, which was by then already seriously deprived and whose future was shrouded in deep uncertainty. Instead of speaking with the German officer, the 86-year-old physician was arrested, brought to Lukiškès and severely beaten. In the end, Wygodzki died in August 1941 at Lukiškès Prison (Brusztein 1957, 53; Agranovskii 1992, 9-10). Other inmates' mental health was severely rattled in the face of the violence being employed by the German forces (Gross 2003, 177). The only benefit the prison offered was that it had a hospital where victims were able to occasionally spend a few days if they were in poor health, allowing them to re-gather their strength (Pasierbska 2003, 105).

\section{Ties to the City: Everyday Life in Lukiškès Prison under German Occupation}

While the standard time of detention for Jewish prisoners was usually limited to a few hours up to a few days, a small number of Jews were temporarily rescued from being deported to Panary to work as labourers either in different spots of Vilna or in the prison itself, wherever there was a shortage. Oswald Rufeisen, a Polish Jew from Upper Silesia, who later became famous as the Catholic priest Daniel, was saved from being taken to Panary thanks to his skills as shoemaker in a workshop established in the prison after a Jewish leather wholesale storage was plundered by the Germans (Tec 2010, 35). Gestapo members had themselves ordered some new boots for their own needs, which meant that Oswald felt the 
prison was more secure than trying to make his way back to the existing ghetto. In his memoirs we find some hints that the prison was not fully isolated from the town. Due to his privileged position as a labourer he even had an opportunity once to meet a friend from the outside.

Communication within the prison was apparently rather lively. Thanks to Morse code, the pipes served as the main conduit of news. Alternatively, papers were handed out from window to window, becoming the prison's so-called 'airmail' system. From other sources we know that Christian inmates were able to partially uphold a religious life. Catholic services were still celebrated and it was possible to send written confessions over a distance of some floors (Pasierbska 2003, 54). To communicate with people in the town, towels were used as letters and other signs shared with inhabitants of the houses nearby. With the help of these inhabitants, Polish inmates were able to make eye contact with their loved ones who were, from time to time, let into the flats near the prison (Pasierbska 2003, 60).

Another aspect of everyday life in the prison were the several lines of conflict that existed between different social groups. The most obvious, but not the only, point of constant tension was between the Lithuanians and Poles. On the one hand, this was due to the fact that the Lithuanian prison administration was manned exclusively with Lithuanian guards while the majority of inmates were Poles, particularly after most of its Jewish inhabitants were sent directly from Łukiszki to be shot in Panary. Attempts to use the German occupation to make Vilna Lithuanian once more after two decades of Polish rule and a short period of Soviet control had a serious impact on the prison itself. This divide became all the more clear when a large number of Polish Roman Catholic clergy were imprisoned and their Lithuanian counterparts took over their parishes and a Vilna seminary was set up with Lithuanian priests (Pasierbska 2003, 130).

All of these events were echoed in Łukiszki, where a large number of priests and nuns were imprisoned and confronted by the Lithuanian administration of Łukiszki. For a majority of their time in prison they were not even allowed to take part in services at the Catholic Church inside the prison. A rather neutralised version of these events has been found in a diary entry written by the prison's chaplain Juozas Baltramonaitis. ${ }^{17}$ The Lithuanian priest had officially been working for the prison administration since 1942, holding regular services for Catholics, providing them with an opportunity to have confession and even baptising moribund inmates among them Jews and Roma (Aliulis 2003, 517ff.). In his diary he wrote about daily events like the regular 'Entlassungai', the German term that belittled the murder in Panary. At the same time Baltramonaitis put forth a great deal of effort to show the effectiveness of the priesthood with

${ }^{17}$ He formally worked until 1 June 1944. 
impressive turnout for its services, confessions or ceremonies for receiving the sacrament. He also took note of the sheer amount of direct and indirect signs of open hostility between Lithuanians and Poles. ${ }^{18}$ The tension between the Lithuanian guards and the more numerous Polish inmates complicated the administration's life considerably and vice versa.

According to Baltramonaitis, on several occasions, the German officer in charge stated openly that his life would be easier if the guards were Polish (Aliulis 2003, 533). As a consequence, there were repeated requests made by the head of the Lithuanian prison administration to treat prisoners less brutally, a clear sign that the everyday level of violence, apart from the open murder, was significant. The prisoners themselves were in constant conflict and among the Poles and Lithuanians nationality seemed to be perhaps the core issue. As a result, signs of horizontal solidarity beyond ones own social group were rare (Aliulis 2003, 533-535).

Beyond the conflict between the prison's Poles and Lithuanians, we learn a great deal more from Baltramonaitis' diary. By 1942, Jews were not seen as potential prisoners anymore, but rather they were just gathered up and immediately sent off to Panary. Space for non-Catholics to worship was almost non-existent, with there being virtually no representation for Orthodox Christian believers during this period of the prison's history. The day-to-day situation for those who remained in the prison steadily worsened from 1942 onwards. Supplies were few and far between and hunger became a regular phenomenon amongst the inmates. Consequently, even inmates that were treated at the prison's still-functioning hospital died from exhaustion (Bubnys 2009, 32).

Lukiškès again became a point of focus for Polish-Lithuanian relations when the Polish Armia Krajowa (AK) launched its attack Akcja Burza on 6 July 1944, an attempt to retake Vilna from the remaining German troops before the Red Army could arrive. It was during these final days of the German occupation in July 1944 that a Lithuanian priest gathered the remaining inmates in the prison chapel. The Polish inmates were told that because Lithuanians were essentially on the Poles' side, they would now release them. Only few days later the Germans would flee from Vilna. From 17 July onward, members of the Armia Krajowa were arrested by the Soviets, interrogated mostly at the former Gestapo headquarters, once more becoming a NKVD facility, and imprisoned at Lukiškès (Zarzycki 2011).

After Soviet power was re-established, Lukiškès' intact infrastructure would go on to serve the Soviet state further as it imprisoned a broad range of Polish and Lithuanian underground activists. Several major waves of detention took places in

18 This is partly due to his optics - for Baltramonaitis nationality played a major role in his perception of what was going on, and his idea of one nationality was clearly an ethnic version of blood-bounded nationality. Once he noticed with sentiment that an inmate had choosen Polish nationality although her mother was Lithuanian and her father was Latvian (Aliulis 2003, 532). 
December 1944 and January 1945. During the second half of the 1940s, the largest group of political prisoners in Lukiškess were members of the Armia Krajowa and other Polish underground organisations, which the Soviet authorities considered suspicious. With nearly all of Vilna's Jews being killed in the years prior to 1944, and the forced exodus of most of the Polish inhabitants of Vilna after 1944, the respective numbers of local inhabitants as detainees in prison declined as well. The areas where they lived in the city, if they were not destroyed during the war, were almost immediately filled by Lithuanians who started to move to Vilna in large numbers at the same time the events described above were taking place. Consequently, the proportion of Lithuanian prisoners in Lukiškés rose steadily throughout the 1940s and 1950s.

With the city's re-established function as a capital of a soviet social republic, Lukiškès became central to the Soviet state's attempts to silence insurrectionist forces that organised in the forest throughout Lithuania. The prison was again used with a close connection to the court building on the Lukiškès Square, where sentencing occurred. But with the Soviet takeover, death sentences were carried out directly inside the KGB interrogatory prison at Lukiškés Square and the bodies were buried at a hidden site on the former estate of Tuskulènai, a few kilometres eastwards from the city centre. The NKVD and KGB's raids against the forest brothers in the region of Vilna led to the capture of partisans, some of them ending up in Lukiškès. Among those who passed through the 'mirtininkai', the death penalty cell, was Edvardas Brinklys. He was sentenced in 1945 for collaborating with German forces and sentenced to death, who said of the ordeal that, 'after the whole investigation was over, and I was brought from the KGB interrogatory prison to the Lukiškès Prison. I was then taken to a room for one person. But there were three of us inside. We slept on the concrete ground and changed upon an agreed command. This is how we waited for our trial. The most threatening weapon we had was our knowledge about the shootings' (Čekutis and Žygelis 2014).

While Lithuanian national public discourse today focuses on ethnic Lithuanians' suffering and a narrative that argues that the era of detention and deportation that unleashed genocidal violence on the local population were the result of Soviet policies, other narratives show a different reality. The large number of Polish and other victims of Soviet political repression that were held in Lukiškes and sent to more remote locations for further detainment lasted up through the late 1940s and beyond (Anušauskas 1996, 109). Even with Vilna once more becoming the capital of the Lithuanian Socialist Soviet Republic, and its related status as one of the central cities of Lithuanian culture, language and history, the prison remained a diverse place echoing the remaining diversity of the city's inhabitants. 


\section{References}

Adams, Bruce, 1996. The Politics of Punishment, DeKalb: Northern Illinois University Press.

Agranovskii, Genrikh and Guzenberg, Irina, 1992. Litovskii Iierusalim, Vilnius: Lituanus.

Aliulis, Vaclovas (ed.), 2003. 'Kalèjimo kapeliono juozo baltrimonaičio dienorašti (1942-1944) suradus', in Lietuviu Kataliku Mokslo Akademijos Metras, (22) 2003, pp. 517-628.

Aliachnovič, Francišak, 1994. Zamiest aŭtabijahrafii - krychu ŭspaminaŭ. U kapciuroch GPU, Minsk: Mastackaja Litaratura.

Anušauskas, Arvydas, 1996. Lietuviu tautos sovietinis naikinimas 1940-1958 metais, Vilnius: Mintis.

Arad, Yitzhak, 2004. The Murder of the Jews in German-Occupied Lithuania (1941-1944), in Nikžentaitis, Alvydas, Schreiner, Stefan and Staliūnas, Darius (ed.), The Vanished World of Lithuanian Jews, Amsterdam and New York: Rodopi, pp. 175-198.

—, 2009. The Holocaust in the Soviet Union, Lincoln: University of Nebraska Press.

Brushtein, Aleksandr, 1957. Doroga ukhodit vdal', Moscow: Detgiz.

Bubnys, Arūnas, 1998. Vokiečiu okupuota Lietuva (1941-1944), Vilnius: Lietuvos Gyventojų Genocido ir Rezistencijos Tyrimo Centras.

Bubnys, Arūnas, and Kuodytè, Dalia, 2005. The Holocaust in Lithuania between 1941 and 1944, Vilnius: Genocide and Resistance Research Centre of Lithuania.

Bubnys, Arūnas, 2009. Lukiškių kalèmas nacistinès okupacijos metais (19411994), non published manuscript of a paper given on behalf of the Lietuvos gyventojų genocido ir rezistencijos tyrimų centras on 7.1.2009, Vilnius: Lietuvos Gyventojų Genocido ir Rezistencijos Tyrimo Centras .

Carlson, Peter, 1999. Prison and Jail Administration: Practice and Theory, Gaithersburg, MD: Aspen Publishers.

Čekutis, Ričardas, and Žygelis, Dalius, 2014. Okupavę Lietuva, sovietai ịsteigè daugybe ikalinimo vietų. Dauguma ju buvo skirtos politiniams priešininkams palaužti bei „perauklèti“. Laisvès kryžkelès (XIX). Pasipriešinimo soviety okupacijai dalyviu kalinimo vietos Lietuvoje, <http://www.bernardinai.lt/ straipsnis/2006-06-05-laisves-kryzkeles-xix-pasipriesinimo-sovietu-okupacijaidalyviu-kalinimo-vietos-lietuvoje/5270/print> [accessed 1 September 2014].

Česnulis, Petras, 1983. In the Shadow of the White Eagle. For Your Freedom and Ours. A Lithuanian's Memoir of Political Captivity in Polish Prisons 1936- 
1939, translated by Šarūnas Daūkša, Paris, Ontario: The Vilnius Region Lithuanian Association.

Dawidowicz, Lucy, 1989. From That Place and Time. Memoirs 1938-1947, New York: W. Norton.

Davoliūtè, Violeta, 2013. The Making and Breaking of Soviet Lithuania. Memory and Modernity in the Wake of War, London and New York: Routledge.

Dieckmann, Christoph, 2011. Deutsche Besatzungspolitik in Litauen 19411944, 2 vol., Göttingen: Wallstein.

Donghi, Daniele, 1925. Manuale dell'architetto 2 (2), Torino: Utet, pp. 75-80.

Fishman, David, 2005. The Rise of Yiddish Culture, Pittsburgh: University of Pittsburgh Press.

Foucault, Michel, 1977. Discipline and Punish, New York: Pantheon Books.

Frank, Stephan, 1999. Crime, Cultural Conflict, and Justice in Rural Russia, 1856-1914, Berkeley: University of California Press.

Gernet, Michail, 1951. Istoriia tsarskoi tiur'my, vol. 2, Moscow: Gosiurizdat.

Girninkienè, Vida, 1991. Egzekucijos 1863-1864 metai Lietuvoje. Straipsniai ir dokumentai, Kaunas: Šviesa.

Goshkevich, Iosif(ed.), 1905. Vilenskaia guberniia. Polnyi spisoknaselionnykh mest so statisticheskimi dannymi o kazhdom poselenii, Vilnius.

Gross, Jan Tomasz, 2003. Revolution from Abroad, Princeton: Princeton University Press.

Gross, Jan Tomasz, and Grudzińska-Gross, Irena, 1983. W Czterdziestym nas matko na Sybir zesłali, London: Aneks.

Hoppe, Bert, and Glass, Hildrun, 2011. Sowjetunion mit annektierten Gebieten I: Besetzte sowjetische Gebiete unter deutscher Militärverwaltung, Baltikum und Transnistrien, München: Oldenbourg.

Jogèla, Vytautas, 2008. Lukiškių sociotopografija (1831-1918 m.): nuo pakraščio centro link, in Vytautas Jogèla, Elmantas Meilus, Virgilijus Pugačiauskas, Lukiškès: Nuo priemieščio iki centro (XV a. - XX a. pradžia), Vilnius: Diemedis.

Johnston, Norman, 2000. Forms of Constraint. A History of Prison Architecture, Urbana and Chicago: University of Illinois Press.

Kapočius, Juozas, 1970-1978. Vileišis, Jonas, in Simas Sužiedèlis (ed.), Encyclopedia Lituanica, vol. VI, Boston: Lietuvių Enciklopedijos Leidykla, pp. 124-125. 
Kriukelyte, Erika, 2014. The Creation of Modern Prisons in the Russian Empire. Research Report, IISH-Research Paper 48, 2012, <http://www.iisg.nl/ publications/respap48.pdf $>$ [accessed 1 August 2014].

Kruk, Herman, 2002. The Last Days of the Jerusalem of Lithuania: Chronicles From the Vilna Ghetto and the Camps, 1939-1944, Yale: Yale University Press.

Kuznitz, Cecile E., 1998. 'On the Jewish Street: Yiddish Culture and the Urban Landscape in Interwar Vilna', in Leonard J. Greenspoon (ed.), Yiddish Language \& Culture: Then \& Now, Omaga, NE: Creighton University Press, pp. 65-92.

LCVA (Lietuvos centrinis valstybės archyvas) F R730, apl. 1, b. 218, 12, 566, 338.

LCVA (Lietuvos centrinis valstybès archyvas) F R730 Opis 1 Akte 1276.

LCVA (Lietuvos centrinis valstybės archyvas) LCVA F R689 ap. 4, b. 916, Masinès žudynès Lietuvoje, d. 1.

Leitanaitè, Rūta, and Reklaitè, Julija (ed.), 2013. Vilnius 1900-2013. A Guide to the City's Architecture, Vilnius: Architekturos Fondas.

Lietuvių enciklopedija, 1958. 'Lukiškès', in: Lietuvių enciklopedija, vol. 16, p. 509, Boston: Lietuvių Enciklopedijos Leidykla.

LMAVB (Lietuvos mokslų akademijos Vrublevskių biblioteka) RS f. 12, b. 2228 .

Łubkowska, Alicja, 2014. 'Wspomnienie o Ewelinie Przyborzance z Wilnem w tle', in Nasz Czas, 11/2006 (686), <http://kurierwilenski.lt/2010/01/29/nawiezienna-nute/ $>$ [accessed 1 April 2014].

Lukiškių tardymo izoliatorius-kalëjimas, <http://www.kaldep.lt/lt/ltik/pradzialtik.html> [accessed 1 July 2014].

Lukšionytè, Nijolè, 1980. Moderno stiliaus gyvenamieji namai: Lietuvos TSR architektūros klausimai, vol. IV, Vilnius: Lietuvos Statybos ir Architekturos Mokslinio Tyrimo Institutas.

MacQueen, Michael, 2003. 'Einheimische Gehilfin der Gestapo. Die litauische Sicherheitspolizei in Vilnius 1941-1994', in Vincas Bartusevičius, Joachim Tauber, Wolfram Wette (ed.), Holocaust in Litauen: Krieg, Judenmorde und Kollaboration im Jahre 1941, Weimar: Böhlau, pp. 104-117.

Ministero di Grazia e Giustizia, 1994. Immagini dal Carcere, Roma: Instituto Poligrafico e Zecca dello Stato.

Pasierbska, Halina, 2003. Wileńskie Łukiszki na tle wydarzeń lat wojny 19391944, Gdańsk. 
Piotrowski, Tadeusz, 2007. Poland's Holocaust: Ethnic Strife, Collaboration With Occupying Forces and Genocide in the Second Republic, 1918-1947, Jefferson, NC: McFarland.

Sacrum Poloniae millennium: rozprawy, szkice, materialy, historyczne, 1965 (11), Rome, pp. 233-250, Rome: Typis Pontificiae Universitatis Gregorianae.

Sakowicz, Kazimierz, 2005. Die geheimen Notizen des K. Sakowicz: Dokumente zur Judenvernichtung in Panary 1941-1943, Frankfurt am Main: Fischer Taschenbuch.

Smaliančuk, Aliaksandr, 2004. Pamiž Krajovasciu i nacyjanaĺnaj idejaj. Poĺski ruch na bielaruskich i litoŭskich zemliach. 1864 - liuty 1917 h., St. Petersburg: Neŭski Prasciah.

Spector, Shmuel, and Wigoder, Geoffrey (ed.), 2001. The Encyclopedia of Jewish Life Before and During the Holocaust, New York: New York University Press.

Stanziani, Alessandro, 2009. 'The Travelling Panopticon: Labor Institutions and Labor Practices in Russia and Britain in 18th and 19th Centuries.', in: Comparative Studies in Society and History, 51 (4), pp. 715-741.

Tec, Nahama, 2010. Lions Den. The Life of Oswald Rufeisen, Oxford: Oxford University Press.

Vinogradov, Aleksandr, 1905. Putievoditel'po gorodu Vil'nie i iego okriesnosti, Vilna: Tipografiia Shtaba Vilenskogo Voiennogo Okruga.

Wardzyńska, Maria, 1993. Sytuacja ludności polskiej w Generalnym Komisariacie Litwy czerwiec 1941 - lipiec 1944, Warszawa: Mako.

Weeks, Theodore R., 1996. Nation and State in Late Imperial Russia: Nationalism and Russification on Russia's Western Frontier, 1863-1914, DeKalb: Northern Illinois University Press.

—, 2013. 'Jews and Others in Vilna-Wilno-Vilnius 1831-1948', in Omer Bartov and Eric D. Weitz (eds), Shatterzone of Empires, Coexistence and Violence in the German, Habsburg, Russian, and Ottoman Borderlands, Indiana: Indiana University Press, pp. 81-102.

Wilczur, Jacek Edward, 2005. Wileński pierścień śmierci, Warszawa: Oficyna Wydawnicza 'Echo'.

Zarzycki, Władysław, 2011. Z Wilna do Workuty. Wspomnienia komendanta garnizonu okręgu wileńskiego AK, Warszawa: Instytut Pamięci Narodowej. 